\title{
Kolaborasi dalam Pengelolaan Kawasan Konservasi Taman Buru Gunung Masigit Kareumbi Provinsi Jawa Barat
}

\author{
Sawitri B. Utami ${ }^{1}$ \\ Ramadhan Pancasilawan ${ }^{2}$
}

\begin{abstract}
ABSTRAK
Pengelolaan dan pengembangan kawasan konservasi ditujukan untuk mengusahakan kelestarian sumber daya alam hayati dan ekosistemnya. Taman Buru Masigit Kareumbi, salah satu kawasan konservasi di Jawa Barat dan satu-satunya Taman Buru Nasional di Pulau Jawa. Terdapat keanekaragaman hayati dan ekosistem yang perlu dijaga sebagai asset nasional. Keterlibatan berbagai pihak seperti, keterlibatan pemerintah pusat dalam hal ini melalui BKKSDA Jawa Barat, Pemerintah Provinsi Jawa Barat, kemudian tiga kabupaten (Kab. Bandung, Kab. Garut dan Kab. Sumedang), keterlibatan Lembaga masyarakat yaitu Wanadri serta masyarakat lokal yang juga memiliki kepentingan dalam pengelolaan kawasan Taman Buru Masigit Kareumbi.

Kegiatan kolaborasi yang dilakukan dalam pengelolaan Kawasan Kareumbi tersebut sudah mengikuti tahapan-tahapan dalam kolaborasi bahkan sampai proses monitoring dan evaluasi. Namun hubungan ini melemah karena tugas dan peran masing-masing pihak tidak dapat dimengerti karena belum ada SOP (Standar Operasional Prosedur) yang menjadi dasar dalam pembagian tugas dan peran tiap stakeholder. Diperlukan aturan yang komprehensif dan turunan dari aturan tersebut tersusun SOP yang sangat jelas mengatur peran dan fungsi tiap stakeholder yang memiliki kepentingan dalam area Taman Buru Masigit Kareumbi.
\end{abstract}

Kata Kunci: Kolaborasi, Taman Buru Masigit Kareumbi, wilayah konservasi alam

\begin{abstract}
Conservation area management is aimed to promote the preservation of the biological ecosystem. Buru Masigit Kareumbi Park, one of the conservation areas in West Java and the only National Buru Park in Java Island. There are biodiversity and ecosystems that need to be preserved as national assets. The involvement of various stakeholders such as, the involvement of the central government in this case through BKKSDA West Java, West Java Provincial Government, then three districts (Bandung, Garut and Sumedang), community institutions Wanadri and local communities who also have an interest in Management of Taman Buru Masigit Kareumbi area.
\end{abstract}

Collaboration Kareumbi Area has been done and also have been following the stages in the collaboration even until the process of monitoring and evaluation. However, this relationship is weakened because the tasks and roles of each stakeholder can not be understood because there is no SOP (Standard Operational Procedure) which becomes the basis in the division of tasks and the role of each stakeholder. Required

\footnotetext{
${ }^{1}$ Dosen Administrasi Publik Fisip Universitas Padjadjaran. Email : sawitri.budi@unpad.ac.id

${ }^{2}$ Dosen Administrasi Publik Fisip Universitas Padjadjaran. Email : ramadhan.pancasilawan@unpad.ac.id
} 
comprehensive rules and derivatives of the rules are compiled SOPs that clearly define the role and function of each stakeholder who has interests in the area of Buru Masigit Kareumbi Park

Key Words: Collaboration, Buru MAsigit Kareumbi Park, Conservation area

\section{Latar Belakang}

Dalam merealisasikan pengelolaan kawasan konservasi Taman Buru Gunung Masigit Kareumbi, BKSDA selaku pemegang kekuasaan dalam melakukan pengelolaan mempunyai visi dan misi sebagai landasan atau acuan dalam menjalankan segala bentuk kegiatannya, visi Balai BKDSA Jawa Barat adalah "Kelembagaan Balai BKSDA Jawa Barat yang kuat untuk menjamin kelestarian dan kemanfaatan konservasi sumberdaya alam hayati dan ekosistemnya di Jawa Barat dan Banten." Dengan misi Balai BKSDA Jawa Barat yaitu :

1. Meningkatkan pengamanan, perlindungan dan pengelolaan kawasan konservasi dan keanekaragaman hayati;

2. Mengoptimalkan kemanfaatan kawasan konservasi untuk kepentingan pendidikan, penelitian, wisata alam dan jasa lingkungan;

3. Menguatkan kelembagaan dan tata kepemerintahan yang baik.

Untuk merealisasikan visi dan misi Balai Besar Konservasi Sumber Daya Alam Jawa Barat, maka diperlukan bantuan dari berbagai pihak, khususnya terlebih bantuan dari Perhimpunan Penempuh Rimba dan Pendaki Gunung Wanadri agar pengelolaan kawasan konservasi Taman Buru Gunung Masigit Kareumbi dapat berjalan dengan baik dan proses kerjasama di antara kedua belah pihak berjalan selaras dan sinergis.

Adanya keterlibatan masyarakat lokal yang sangat tinggi khususnya di wilayah kawasan konservasi Taman Buru Masigit Kareumbi dalam mengelola kawasan konservasi. Hal itu sangat membantu sekali baik bagi Balai Besar Konservasi Sumber Daya Alam Jawa Barat maupun Wanadri. Masyarakat di ajak untuk belajar dalam mengelola kawasan hutan dengan diberikan pelatihan, pembelajaran, dan pendidikan.

Namun dalam pengelolaan yang dilakukan masih ada beberapa permasalahan yang terjadi, hal itu terlihat dengan adanya $\mathrm{MoU}$ (Memorandum of Understanding) yang telah dibuat dan disepakati bersama. Tetapi pada implementasi atau pelaksanaan di lapangan MoU tersebut belum dijalankan secara optimal, hal ini disebabkan karena klausulnya terlalu general atau umum dan perlu didetailkan untuk memudahkan operasionalnya. Sehingga para pihak khususnya BBKSDA dan Wanadri memahami secara jelas tugas dan perannya masing-masing dalam melakukan pengelolaan.

Dengan demikian dalam menyusun model kolaborasi yang dapat dilakukan salah satunya menggunakan konsep kolaoborasi dari dari Vigoda dan Gilboa (2002), yang menjelaskan kolaborasi dari awal karakteristik masalah sampai evaluasi kolaborasi tersebut.

\section{Rumusan Masalah}

Pengelolaan kawasan Taan buru Nasional di Jawa Barat seharusnya menjadi perhatian banyak pihak sebab didalamnya menjadi penyangga kehidupan manusia dan juga tempat pelestarian keanekaragaman tumbuhan dan satwa serta ekosistemnya. Namun masih ada permasalahan dalam pengelolaan kawasan yang sebenarnya sudah ada banyak pihak yang memiliki peran dalam pengelolaan kawasan tersebut. Dengan demikian dalam kajian ini mengidentifikasikan masalah sebagai berikut:

1. Bagaimana peran stakholder dalam pengelolaan kawasan Taman Buru Masigit Kareumbi Jawa Barat?

2. Bagaimana model kolaborasi dalam penge- 
lolaan kawasan Taman Buru Masigit Kareumbi Jawa Barat?

\section{Tujuan Penelitian}

Tujuan khusus penelitian ini adalah teridentifikasi model kolaborasi dalam pengelolaan kawasan Taman Buru Masigit Kareumbi Jawa Barat.

\section{Kolaborasi dalam Perspektif Administrasi Publik}

Di dalam perspektif administrasi publik, kolaborasi merupakan kerja secara bersama atau bisa dikatakan bekerja bersama dengan beberapa pihak yang terkait di dalam suatu kegiatan untuk mencapai tujuan. Hal ini tentu pula sependapat dengan pengertian dari administrasi itu sendiri, administrasi merupakan suatu kerjasama antara dua orang atau lebih untuk mencapai suatu tujuan.

Untuk mengetahui posisi kolaborasi dalam konteks administrasi publik dilakukan dengan mencermati konsep tersebut dari berbagai perspektif keilmuan. Dalam literatur administrasi publik sering digunakan terminologi governance untuk menjelaskan keterkaitan antarorganisasi. Pengertian governance tidak sekedar perlibatan lembaga publik dalam formulasi dan implementasi kebijakan, tetapi terhubungnya berbagai organisasi untuk melaksanakan tujuan-tujuan publik.

Di dalam buku Collaborative Governance a New Era of Public Policy in Australiaoleh Janine O'Flynn dan John Wanna dijelaskan bahwa kolaborasi bisa dilakukan di organisasi pemerintah untuk memecahkan permasalahan yang kompleks serta untuk mencapai tujuan secara efektif dan tepat sasaran. Sistem pembelajaran dan pendidikan di Australia sudah menerapkan berbagai model kolaborasi. Di Queensland, The Queensland Departement of Education, Training, and the Arts (DETA) melakukan kolaborasi dengan tiga sektor sekolah yaitu negara, katolik, dan pihak independent. Kolaborasi yang dilakukan itu untuk mencapai goalatau hasil yang ingin dicapai, hasil yang ingin DETA capai adalah untuk mecerdaskan, skill yang mumpuni, dan kreatif khususnya di Queensland.

Dari penjelasan di atas, kolaborasi bisa di aplikasikan pada sektor publik. Keterbatasan dari pemerintah sebagai pelayan publik untuk mencapai suatu goalatau hasil yang baik perlu melibatkan pihak lain agar dapat mencapai hasil tersebut secara maksimal. Di sadari bahwa kolaborasi itu ada karena adanya sifat saling membutuhkan antarorganisasi dalam mengurusi suatu permasalahan atau kegiatan.

\section{Pengertian Kolaborasi}

Kolaborasi dibutuhkan pada setiap level organisasi, karena pada hakekatnya kolaborasi adalah suatu kerjasama.Kolaborasi dapat berlangsung dalam dua konteks, yaitu di dalam organisasi (internal organisasi) serta kerjasama eksternal organisasi atau interorganizational relations yang dilakukan beberapa organisasi (dua atau lebih) dalam rangka mencapai tujuan tertentu. Hal ini sejalan dengan para ahli yang mengemukakan definisi kolaborasi menyangkut konteks kerjasama internal dan eksternal organisasi, diantaranya adalah David Strauss dalam bukunya How To Make Collaboration Work dan Russel M. Linden dalam bukunya Working Across Boundaries. Strauss mengemukakan bahwa:

Kolaborasi menunjuk pada proses mempekerjakan orang ketika bekerjasama dalam suatu grup, organisasi, atau komunitas untuk merencanakan, membuat, memecahkan masalah, dan membuat keputusan. (Straus: 2002:5)

David Strauss mengemukakan bahwa kolaborasi ada di dalam organisasi juga ada di antara dan di sekitar mereka yang melakukan kerjasama. Mereka menyediakan orang untuk bekerja bersama untuk merencanakan, memecahkan masalah, dan membuat keputusan sebelum mengambil tindakan. Dari pendapat David Strauss tersebut dapat dilihat bahwa dalam melakukan kolaborasi semuanya dilakukan dan diputuskan bersama-sama

Kolaborasi yang dikemukakan oleh 
Linden dan Strauss tersebut menjelaskan bagaimana hubungan yang terjadi antar organisasi pemerintah (government to government cooperation) serta antara organisasi pemerintah dan organisasi non pemerintah (public-private sector coordination). Kemudian ahli lain seperti Agranoff \& Mc Guire, mendefinisikan kolaborasi dengan menitikberatkan pada hubungan interorganisasi saja, sebagaimana dijabarkan dalam suatu definisi sebagai berikut:

"Manajemen kolaboratif adalah sebuah konsep yang menggambarkan proses fasilitasi dan pengoperasian dalam rencana multiorganisasional untuk memecahkan masalah yang tidak dapat dipecahkan atau dipecahkan dengan mudah oleh satu organisasi. kolaborasi adalah desain relasi purposif untuk memecahkan masalah dengan menciptakan atau menemukan solusi dalam sebuah situasi yang mendesak. (misalnya: pengetahuan, waktu, uang, kompetisi, dan adat istiadat." (Agranoff \& Mc Guire: 2003,4).

Agranoff \& Mc Guire mengembangkan konsep kolaborasi pada city level collaboration dalam konteks pembangunan ekonomi, sehingga pihak yang terlibat tidak hanya intergovernmental domain tapi juga nongovernmental sector.

Berkaitan dengan itu, kolaborasi pada hakikatnya adalah suatu kerjasama yang dilakukan antar organisasi untuk mencapai tujuan bersama yang tidak mungkin atau sulit dicapai apabila dilakukan secara mandiri. Dalam konteks ini terkandung dua hal penting; (1) setiap organisasi pada awalnya adalah mandiri; (2) karena adnanya kebutuhan mencapai tujuan masing-masing yang terfokus pada tujuan obyek yang sama, organisasi melakukan kerjasama.Hubungan yang terjadi di dalam kolaborasi adalah relasi purposive, dimana tidak semua unit dalam organisasi melakukan usaha bersama hanya unit yang memiliki spesifikasi tugas tertentu yang sesuai dengan pencapaian tujuan atau permasalahan yang hendak dipecahkan organisasi lainlah yang melakukan joint effort (usaha bersama).

Berdasarkan pengertian-pengertian di atas, kolaborasi merupakan suatu usaha kerjasama atau bekerja bersama antara organisasi pemerintah maupun non pemerintah seperti LSM, atau lembaga lainnya untuk mencapai suatu tujuan bersama-sama. Latar belakang adanya kolaborasi didasarkan atas keterbatasan kemampuan pemerintah dalam mengelola suatu hal seperti halnya bentuk permasalahan ataupun kegiatan, maka dari itu pemerintah mengajak pihak lain untuk bekerja bersama yaitu dengan kolaborasi.

\section{Proses, Prinsip dan Kerangka Kolaborasi}

Proses merupakan tahapan-tahapan yang harus dilalui sebelum mencapai suatu tujuan. Proses kolaborasi merupakan tahapan-tahapan yang harus dilakukan agar tujuan bersama yang telah ditetapkan dapat tercapai. Richard (Raharja; 2008:9) mengemukakan kolaborasi merupakan proses yang bersifat incremental melalui beberapa tahapan;

1. Pengembangan visi kolaborasi yang menjelaskan kepentingan bersama.

2. Approaches to visioning dalam bentuk penyamaan pemahaman dan pengalaman kolektif. Hasilnya didokumentasikan dalam bentuk prinsip-prinsip operasi sebagai referensi bagaimana stakeholder bekerja.

3. Appreciative inquiry, yaitu alat untuk mencari cara yang lebih baik, efektif dan konstruktif yang meliputi four $D$ :

a. Discovery berkaitan dengan menemukan yang terbaik;

b. Dream berkaitan dengan visi yang ingin dihasilkan;

c. Design berkaitan dengan apa yang diperbuat;

d. Deliver bagaimana desain diterapkan/ dilaksanakan"

Richard dalam buku yang ditulis Raharja mengemukakan bahwa proses kolaborasi harus memiliki tujuan yang dapat dipahami bersama 
dan memiliki prinsip-prinsip yang mendukung tercapainya tujuan.

Pendapat lain berkaitan dengan proses kolaborasi, dikemukakan oleh Chris dan Vangen (1996: 5-17), yang merumuskan enam tahapan dalam kolaborasi antarorganisasi yaitu:

1. Managing aims (Penetapan Tujuan).

2. Compromise (Kompromi).

3. Communication (Komunikasi).

4. Democracy dan equality (Demokrasi dan Kesetaraan).

5. Power dan trust (Kekuatan dan Kepercayaan).

6. Determination, commitment dan stamina (Ketetapan, komitmen dan kesanggupan).

Dalam enam tahapan ini dijelaskan bahwa setiap anggota kolaborasi memiliki tujuan bersama. Pendapat Chris dan Vangen tersebut pendapat bahwa hal yang pertama dalam melakukan kolaborasi adalah penyamaan tujuan. Kemudian harus adanya pemahaman agar perbedaan yang terjadi dalam gaya kerja, norma dan nilai organisasi tidak menimbulkan perpecahan. Kemudian dengan adanya komunikasi yang intensif dan efektif menjadikan kolaborasi lebih dapat berjalan dengan baik. Semua anggota harus diajak dalam melakukan langkah-langkah kolaborasi secara bersamasama agar menciptakan kepercayaan dan komitmen yang kuat agar tercapainya tujuan.

Selain itu, Ann Marie Thompson dalam jurnalnya yang berjudul "Collaboration Process: Inside The Black Box." Mengungkapkan bahwa ada 5 dimensi kunci dalam kolaborasi yaitu: 2 dimensi struktural (pengelolaan dan administrasi), 2 dimensi sosial kapital (hubungan timbal balik dan norma-norma), dan satu lagi adalah dimensi agensi (otonomi organizational).

Untuk memahami proses kolaborasi baiknya melalui platform analisis sistem, dimana menurut Vigoda dan Gilboa (2002), memberikan sebuah gambaran umum di dalam kolaborasi yang dilakukan antara pemerintah dan para stakeholders yang terkait di dalamnya. Terdiri dari enam tahap di dalam prosesnya, antara lain:

1. Memutuskan sebuah masalah di dalam kolaborasi. (Deciding on a fitting issue for collaborating)

Proses kolaborasi yang baik dapat dimulai dengan sebuah masalah yang sesuai dan memiliki manfaat. Disini kolaborasi dapat mampu membuktikannya melalui dua kondisi utama : (1) ketika sebuah masalah diusahakan untuk diinvestasikan bersamasama dengan membuat sebuah kelompok kerja, (2) ketika terdapat alasan yang bagus untuk percaya dimana disini adanya kekuatan dan pengaruh dari orang-orang yang begabung di dalam kelompok yang secara signifikan memiliki kekuatan yang lebih besar.

2. Karakteristik masalah tersebut melalui pertanyaan "what and where". (Characterizing the issue by what and where inquires)

Kolaborasi membutuhkan karakter kerja individu yang selalu siap berpartisipasi dalam kolaborasi, dan mengharapkan orang lain untuk berpartisipasi. Dan setiap individu harus cerdas bernegosiasi, saling berkontribusi dalam kerja sama, untuk menemukan titik tengah dari solusi yang diinginkan. Hubungan timbal balik yang adil dan terbuka merupakan dasar untuk menghasilkan iklim kolaboratif yang efektif dan efisien untuk kepentingan organisasi.

3. Mencari tahu siapa saja yang terlibat. (Finding out who is involved)

Di dalam kolaborasi para stakeholders yang terlibat didalamnya mempunyai kesamaan tujuan bersama para stakeholders harus meningkatkan komitmen, kepercayaan, dan keyakinan di dalam perencanaan tujuan bersama di dalam proses kolaborasi. Sehingga, para stakeholders ini memiliki keefektifan serta efisiensi di dalam menjalankan kolaborasi kebersamaan.

4. Mencari tahu bagaimana pengimplementasiannya. (Finding out how to implement)

Kolaborasi yang efektif terwujud dari berbagai proses pendewasaan atas komunikasi, kerjasama, ketulusan, keikhlasan, dan fleksibilitas. Mengakui bahwa kolaborasi adalah sebuah perjalanan. Keterampilan dan pengetahuan yang 
dibutuhkan untuk kolaborasi yang efektif membutuhkan waktu dan praktek.

5. Menyelenggarakan kolaborasi. (Launching implementation)

Agar penyelenggaraan program ini dapat berjalan dengan baik setidaknya terdapat hal yang harus dilakukan, antaranya : para stakeholders bersama-sama melakukan program tersebut dengan metode yang sudah ditentukan bersama dan memikirkan kembali dan mendefinisikan tujuan serta menentukan indikator-indikator kerja untuk seluruh proses kolaborasi.

6. Mengevaluasi proses tersebut. (Evaluating the process)

Evaluasi merupakan peran instrumental dari hasil proses kolaborasi bersama di dalam kolaborasi, dimana menilai dampak dan perubahan bagi organisasi tersebut, bagi anggota organisasi, atau bagi masyarakat yang mereka layani.

Kolaborasi dalam pengelolaan kawasan konservasi Taman Buru Gunung Masigit Kareumbi terjadi karena adanya hubungan saling ketergantugan dalam mengelola kawasan hutan konservasi. Pengelolaan kawasan konservasi khususnya Taman Buru Gunung Masigit Kareumbi yang cukup sulit dikelola oleh Balai Besar Konservasi Sumber Daya Alam dikarenakan keterbatasan sumber daya yang dimiliki maka dibutuhkan peran dari pihak lain dalam membantu pengelolaan yaitu Wanadri dan masyarakat sekitar kawasan Taman Buru Gunung Masigit Kareumbi. Dengan demikian dengan menggunakan konsep Vigoda dan Gilboa (2002) juga menjelaskan bahwa kolaborasi terjadi ketika adanya orang dari berbagai pihak terkait untuk bekerjasama dalam merencanakan, membuat, memecahkan masalah, dan membuat keputusan. Hal ini pun sesuai dengan kolaborasi yang dilakukan oleh BBKSDA dan Wanadri dalam melakukan pengelolaan kawasan konservasi Taman Buru Gunung Masigit Kareumbi. Kedua belah pihak bekerjasama dan menempatkan orang-orang dalam melakukan pengelolaan.

Dalam pelaksanaan kolaborasi kawasan konservasi Taman Buru Gunung Masigit Kareumbi, Balai Besar Konservasi Sumber Daya Alam merupakan lembaga dari lingkungan pemerintah yang mengelola kawasan konservasi dengan di bantu beberapa unit lembaga seperti Bidang KSDA Wilayah II Soreang, Seksi Wilayah III KSDA Soreang dan Resort Masigit Kareumbi Barat. Dan Perhimpunan Penempuh Rimba dan Pendaki Gunung Wanadri sebagai lembaga non pemerintah yang melakukan kerjasama dengan BBKSDA terkait pengelolaan kawasan konservasi Taman Buru Gunung Masigit Kareumbi.

Secara teoritis diharapkan pelaksanaan kolaborasi antar instansi yang merupakan aktifitas pengintegrasian dan penyelarasan seluruh kegiatan dari berbagai unit kerja dan personil yang berlainan fungsi dan instansi, dengan berpedoman kepada proses dalam kolaborasi, dapat menghasilkan kolaborasi pengelolaan kawasan konservasi Taman Buru Masigit Kareumbi yang efektif, selaras, dan sinergis sebagaimana yang diharapkan dalam Peraturan Menteri Kehutanan Nomor : P.19/Menhut-II/2004 tentang Kolaborasi Pengelolaan Kawasan Suaka Alam dan Kawasan Pelestarian Alam.

\section{Metode}

Dalam penelitian ini penulis menggunakan metode kualitatif. Kemudian dalam penelitian ini penulis menggunakan beberapa teknik dalam mengumpulkan data yang dikumpulkan penyusun berdasarkan sumber datanya, dalam penyusunan penelitian ini dibagi menjadi dua bagian, yaitu:

\section{Data Primer}

Data Primer merupakan data yang dikumpulkan penyusun dari perusahaan, instansi, badan, lembaga atau organisasi yang diteliti, dalam hal ini Balai Besar Konservasi Sumber Daya Alam Jawa Barat dan Perhimpunan Penempuh Rimba dan Pendaki Gunung Wanadri. Pengumpulan data ini dilakukan dengan cara wawancara dengan pihak yang terkait langsung dengan objek 
penelitian ini, dan observasi partisipan.

\section{Data Sekunder}

Data sekunder merupakan data pendukung data primer. Data ini diperoleh melalui literatur-literatur, laporan-laporan ilmiah dan sumber data lain yang memiliki keterkaitan dengan penelitian yang dilakukan, yang dimaksudkan untuk memperoleh landasan teoritis.

Adapun teknik pengumpulan data yang penyusun gunakan adalah :

1. Studi Literatur (kepustakaan)

2. Penelitian lapangan (field research), Melakukan penelitian langsung dapat berguna untuk mengetahui permasalahan yang terjadi sekaligus untuk memperoleh data primer yang dibutuhkan. Adapun data dan informasi dikumpulkan dengan cara:

a) Observasi, Teknik observasi yang digunakan dalam penelitian ini adalah observasi partisipasi pasif (passive participation), yaitu teknik pengumpulan data yang dilakukan melalui pengamatan langsung ke Balai Besar Konservasi Sumber Daya Alam, Bidang KSDA Wilayah II Soreang, KSDA Seksi Wilayah III Soreang, Resort Masigit Kareumbi Barat dan Perhimpunan Penempuh Rimba dan Pendaki Gunung Wanadri. Dalam observasi ini penyusun mengumpulkan data yang berhubungan dengan objek yang diteliti dengan tidak terlibat langsung dalam proses pekerjaannya.

b) Wawancara mendalam (in depth interview), tanya jawab langsung dengan pihak yang bersangkutan dan berkompeten, dalam hal ini yakni para pegawai Balai Besar Konservasi Sumber Daya Alam Jawa Barat, Bidang KSDA Wilayah II Soreang, KSDA Seksi Wilayah III Soreang, Resort Masigit Kareumbi Barat dan Perhimpunan Penempuh Rimba dan Pendaki Gunung
Wanadri sebagai informan untuk memperoleh informasi yang berkaitan langsung dengan masalah yang diteliti.

c) Dokumen, yang digunakan dalam penelitian ini berupa peraturan-peraturan/ arsip-arsip yang berhubungan dengan implementasi kebijakan pengelolaan Kawasan Konservasi Taman Buru Gunung Masigit Kareumbi. Studi dokumen ini merupakan pelengkap dari penggunaan metode observasi dan wawancara dalam penelitian kualitatif ini.

\section{Pengelolaan Kawasan Konservasi Hutan Gunung Masigit Kareumbi}

Menurut sejarah dalam pengelolaannya, awal mulanya pengelolaan kawasan konservasi hutan Gunung Masigit Kareumbi dikelola oleh Dinas Kehutanan Provinsi Jawa Barat pada periode 1950an. Dalam perjalanan pengelolaannya, kawasan hutan Gunung Masigit Kareumbi dijadikan tempat hutan wisata Melalui SK. Menteri Pertanian No 297/Kpts/Um/5/1976 tanggal 15 Mei 1976 kawasan ini ditetapkan sebagai Hutan Wisata dengan fungsi Taman Buru. Lalu pada periode ini tahun 1970-1988, dibuatlah Rencana Pengelolaan (Management Plan) Hutan Wisata Buru Gunung MasigitKareumbi Tahun 1979 - 1984 oleh Direktorat Jenderal Perlindungan Hutan dan Pelestarian Alam. Dalam rencana pengelolaan tersebut, dilakukan pembagian zonasi ke dalam 4 zona, yaitu:

1. Zona Semi Perlindungan (Wilderness Zone) seluas $\pm 7.800,7$ ha.

2. Zona Rekreasi (Intensive Use Zone) seluas \pm 520 ha.

3. Zona Perlindungan (Sanctuary Zone) seluas \pm 4.100 ha.

4. Zona Penyangga (Buffer Zone) meliputi areal berjarak $\pm 500 \mathrm{~m}$ dari batas kawasan ke arah luar.

Kemudian pada tahun 1990 dilakukan program Perencanaan Tapak (site plan) oleh Fakultas Kehutanan IPB kerja sama dengan BKSDA III. Dalam dokumen tersebut 
pembagian kewilayahan kawasan dilakukan sebagai berikut:

1. Zona pengelolaan di Blok KW, Ciceuri, Cipancar dan Cibugel, Cikudalabuh.

2. Zona pengembangbiakan satwa buru di blok KW dan Cibugel.

3. Zona buru yang merupakan sebagian besar kawasan.

4. Zona non-buru di Blok Cipancar dan Ciceuri.

5. Zona penyangga diluar kawasan.

Dan pada tahun 1992 dilakukan kembali program pembuatan rencana pengelolaan (management plan) dari Direktorat Jenderal PHPA yang disusun oleh PT. Aristan Ekawasta. Dalam konsep tersebut, kawasan dibagi dalam:

1. Zona pengelolaan intensif.

2. Zona penangkaran.

3. Zona peliaran dan perlindungan satwa buru.

4. Zona padang buru di blok Ciceuri.

5. Zona wisata alam lainnya.

6. Zona desa binaan/ daerah penyangga.

Dalam perjalanannya kawasan ini kemudian ditetapkan melalui SK. Menhut No. 298/Kpts-II/98 tanggal 27 Pebruari 1998 dan nama resminya adalah Taman Buru Gunung Masigit Kareumbi.

Kemudian setelah itu diterbitkan surat dari Menteri Kehutanan No. 235/Menhut/II/1998, tanggal 25 Februari 1998 yang menyetujui bahwa Hak pengusahaan Taman Buru Gunung Masigit Kareumbi diserahkan kepada PT. Prima Multijasa Sarana (PMS) yang berada di blok pemanfaatan dan blok buru seluas $7.560,72$ ha. Sedangkan sisanya seluas 4809,98 ha yang didalamnya terdapat tegakan pinus, hak pengusahaannya diserahkan kepada Perum Perhutani. Hak pengusahaan tersebut mencakup ijin untuk memanfaatkan dan menyadap getah. Dalam perjalanannya kawasan ini kemudian ditetapkan melalui SK. Menhut No. 298/KptsII/98 tanggal 27 Pebruari 1998 dan nama resminya adalah Taman Buru Gunung Masigit Kareumbi. Surat Sekretaris Jenderal Departemen Kehutanan No. 733/II/Kum/1998 Tanggal 16 April 1998, tentang Ijin Prinsip Taman Buru Gunung Masigit Kareumbi dinyatakan bahwa ijin Pengusahaan Perburuan bertanggung jawab atas kelestarian fungsi kawasan. Selain itu, kepada Perum Perhutani diberi kesempatan untuk menyadap getah pinus dan tidak untuk memanfaatkan kayu. Berdasarkan Keputusan Menteri Kehutanan dan Perkebunan No. 923/Kpts-II/1999 Tanggal 14 Oktober 1999, diberikan ijin Pengusahaan Taman Buru kepada PT. PMS pada blok pemanfaatan Taman Buru Gunung Masigit Kareumbi.

Namun dalam perjalanannya, PT. Prima Multijasa Sarana melakukan suatu pelanggaran dengan melakukan penebangan hasil hutan terutama kayu, kayu tersebut didapatkan dari pohon pinus yang berada di Kawasan Hutan Taman Buru Masigit Kareumbi. Awal mulanya PT. Prima Multijasa Sarana mempunyai site plan, Pada sekitar tahun 2000 - 2001, PT. Prima Sakti Multi Jasa Sarana mendapatkan hak pengelolaan kawasan untuk keperluan pelestarian, taman buru dan wisata alam terbatas. Kemudian dibangun fasilitas bermain untuk anak dan fasilitas outbond di blok Cigoler. Sampai tahun 2005, dibangun Pusat Informasi, Wisma Pemburu, kompleks taman safari mini, kolam renang, rumah sakit hewan dan mesjid, dan kemudian pihak pengelola memutuskan menganti nama "Taman Buru" menjadi "Taman Wisata" karena obyek wisata yang ada didalamnya tidak hanya mencakup wisata buru saja. Dan pengesahan mengenai perubahan nama masih dalam proses. Terdapat empat blok yang ada pada Taman Buru Masigit Kareumbi, pembagian blok tersebut di buat berdasarkan fungsi dari tiap - tiap blok yang terdapat di Taman Buru Masigit Kareumbi adapun blok blok tersebut adalah :

1. Blok Ciceur dimana blok ini di fungsikan sebagai area wisata buru,

2. blok Cibugel, blok ini di fungsikan sebagai area penagkaran Rusa Sambar dan beberapa hewan lainya.

3. Blok Cigoler difungsikan sebagai kawasan wisata keluarga dimana pada blok ini terdapat sebuah taman safari mini lengkap dengan area bermain dan fasilitas outbound.

4. Blok Cipancar difungsikan sebagai area perkemahan, di blok ini juga terdapat area pemanfaatan yang berfungsi sebagai area pendidikan dan latihan. 
Site plan PT Prima Multijasa Sarana terhadap Kawasan Hutan Masigit Kareumbi untuk dijadikan kawasan Taman Buru yang sesuai dengan izinnya yaitu pengusahaan Taman Buru tetapi ketika diperjalanan isi dari perjanjian tersebut dilanggar, mereka menyalahgunakan izin tersebut dengan mengeksploitasi Kawasan Hutan Taman Buru Masigit Kareumbi dan semenjak hal itu hak pengelolan kawasan gunung kareumbi atas PT. Prima Multijasa Sarana dicabut. Dan akhirnya pengelolaan atas Kawasan Konservasi Tama Buru Masigit Kareumbi kembali di pegang dan di ambil alih oleh Balai Besar Konservasi Sumber Daya Alam (BBKSDA) Jawa Barat.

Semenjak peristiwa tersebut, Kawasan Hutan Wisata Gunung Masigit Kareumbi menjadi rusak dan terbengkalai. Hal itu diperkuat dengan banyaknya perusakan dan perburuan liar yang dilakukan oleh para oknum. Melihat hal itu pada sekitar tahun 2006, sesepuh Wanadri yang sering melakukan perjalanan ke kawasan ini, Remi Tjahari (W-090-LANG) melihat potensi kawasan yang sangat besar. Namun di balik potensi kawasan sebagai daerah konservasi dan sangat layak dikembangkan untuk wisata dan pendidikan alam terbuka juga terdapat potensi kerusakan lingkungan bila tidak dikelola dengan baik. Maka timbul suatu ketertarikan dalam megelola kawasan Taman Buru Masigit Kareumbi, hal itu sejalan dan menjadi kewajiban bagi Wanadri yang sesuai dengan isi salah satu hakekat Wanadri yaitu "menjaga alam dan melestarikan sumber daya alam dengan segala isinya."

Akhirnya pada tahun 2007, Perhimpunan Penempuh Rimba dan Pendaki Gunung Wanadri menyampaikan minat untuk melakukan pengelolaan kawasan pada pihak Kementrian Kehutanan dan BBKSDA. Hal itu pun di sambut baik oleh Kepala Balai Besar Konservasi Sumber Daya Alam, tetapi dalam proses pengajuan kerjasama antara Wanadri dengan BBKSDA mengalami kendala, dikarenakan proses kerjasama yang cukup lama dan berbelit. Hampir sekitar satu tahun proses kerjasama itu tidak berjalan.

Setelah menempuh berbagai kewajiban diantaranya pembuatan Rencana Jangka Pendek dan Menengah, pada bulan April tahun 2008, Balai BKSDA Jawa Barat mengeluarkan surat keputusan No: 750/ BBKSDA JABAR.1/ 2008. Lalu pihak dari Wanadri melakukan audiensi dengan pemerintah pusat yaitu Menteri Kehutanan dan Direktorat Jenderal PHKA dengan menjelaskan maksud dan tujuannya melakukan kerjasama dalam pengelolaan kawasan Taman Buru Masigit Kareumbi. Setelah itu pemerintah pusat pun menyambut baik khususnya Menteri Kehutanan yang waktu itu dijabat oleh Bapak MS Kaban. Kemudiansurat keputusan direvisioleh SK No. 1111/BBKSDA JABAR.1/2009 yang pada intinya menyatakan bahwa Balai BKSDA JawaBarat setuju untuk melakukan kerjasama kemitraan Optimalisasi Pengelolaan Kawasan dengan Wanadri dan mekanisme kerjasamanya ditelurkan kedalam dokumen tersebut dengan diketahui oleh Departemen Kehutanan.

Peneliti merasa tertarik untuk meneliti kolaborasi dalam pengelolaan kawasan konservasi Taman Buru Masigit Kareumbi yang merupakan usaha bersama oleh berbagai pihak, baik pemerintah, NGO (Non Government Organization), dan masyarakat. Kolaborasi pada dasarnya merupakan bentuk kerjasama antarorganisasi yaitu antara organisasi pemerintah dengan organisasi non-pemerintah. Kolaborasi terjadi karena adanya ketergantungan (interdepedence) antara satu organisasi dengan organisasi lainnya untuk mencapai suatu tujuan yang sulit dicapai secara mandiri. Peneliti memiliki ketertarikan untuk meneliti hal tersebut, di karenakan dalam melakukan pengelolaan kawasan konservasi Taman Buru Masigit Kareumbi di kelola oleh berbagai pihak baik dari pemerintah yaitu Balai BKSDA Jawa Barat sebagai pemegang kewenangan dalam melakukan pengelolaan, NGO (Non Government Organization) yaitu Wanadri sebagai organisasi pemerhati lingkungan dan juga keterlibatan masyarakat yang berperan dalam ikutserta menjaga, melindungi serta melestarikan kawasan konservasi Taman Buru Masigit Kareumbi. Adanya berbagai permasalahan yang terjadi di dalam kawasan konservasi Taman Buru Masigit 
Kareumbi, seperti halnya penebangan pohon secara illegal, kebakaran hutan, dan perburuan binatang menjadikan alasan kenapa peneliti tertarik untuk meneliti. Kita mengetahui secara jelas lingkungan alam dan ekosistem yang ada di dalam kawasan konservasi perlu di jaga kelestariannya karena menjadi penyangga kehidupan bagi masyarakat banyak dan masyarakat sekitar.

Data-data tersebut diperoleh dari hasil penelitian melalui studi kepustakaan dan studi lapangan yaitu observasi, dan wawancara yang dilakukan terhadap informan yang terdiri dari Kepala Balai Besar Konservasi Sumber Daya Alam Jawa Barat, Kepala Sub Bagian Perencanaan dan Kerjasama KSDA Jawa Barat, Kepala Seksi Wilayah II KSDA Jawa Barat, Kepala Resort Bandung, Ketua Manajemen Pengelola Taman Buru Masigit Kareumbi (TBMK).

\section{Pembahasan}

Untuk memahami proses kolaborasi baiknya melalui platform analisis sistem, dimana menurut Vigoda dan Gilboa (2002), memberikan sebuah gambaran umum di dalam kolaborasi yang dilakukan antara pemerintah dan para stakeholders yang terkait di dalamnya. Terdiri dari enam tahap di dalam prosesnya, antara lain:

1. Memutuskan sebuah masalah di dalam kolaborasi. (Deciding on a fitting issue for collaborating)

Proses kolaborasi dalam pengelolaan Taman Buru Masigit terjadi karena adanya permasalahan yang terjadi dalam pengelolaan Taman Buru Masigit tersebut. Permasalahan itu muncul berupa masih banyaknya pembalakan liar yang dilakukan oleh penduduk sekitar dan juga belum dikelolanya Taman tersebut dengan baik.

Adanya berbagai permasalahan yang terjadi di dalam kawasan konservasi Taman Buru Masigit Kareumbi, seperti halnya penebangan pohon secara illegal, kebakaran hutan, dan perburuan binatang menjadikan alasan kenapa peneliti tertarik untuk meneliti. Kita mengetahui secara jelas lingkungan alam dan ekosistem yang ada di dalam kawasan konservasi perlu di jaga kelestariannya karena menjadi penyangga kehidupan bagi masyarakat banyak dan masyarakat sekitar.

Hal ini menjadi perhatian lebih oleh pemerintah dan juga organisasi masayarakat yang memiliki kepedulian dalam penge-lolaan Taman Buru Masigit tersebut. Oleh karena itu dibuatlah kerjasama antara Balai BKSDA Jawa Barat dan Wanadri dalam melakukan pengelolaan kawasan konservasi Taman Buru Masigit Kareumbi di dasarkan atas Peraturan Menteri Kehutanan Nomor : P.19/MenhutII/2004 tentang Kolaborasi Pengelolaan Kawasan Suaka Alam dan Kawasan Pelestarian Alam. Dengan adanya kolaborasi oleh berbagai pihak dalam melakukan pengelolaan kawasan konservasi Taman Buru Masigit Kareumbi di harapkan dapat membantu untuk meminimalisir terhadap permasalahan yang ada.

2. Karakteristik masalah tersebut melalui pertanyaan "what and where". (Characterizing the issue by what and where inquires)

Kolaborasi membutuhkan karakter kerja individu yang selalu siap berpartisipasi dalam kolaborasi, dan mengharapkan orang lain untuk berpartisipasi. Dalam pengelolaan Kawasan Masigit, stakeholder yang sangat berpartisipasi adalah Wanadri, sebab bagi mereka Kawasan Masigit sangat bagus dan sangat disayangkan apabila kawasan ini justru rusak tidak terawat. Bahkan oleh mereka kawasan ini dikelola dengan baik dan kerap dijadikan lokasi untuk ketangkasan bagi organisasi pecinta alam. Sedangkan hubungannya dengan BKSDA, bahwa Wanadri memiliki sumber daya yang dapat optimal dalam mengelola kawasan tersebut. Maka dari itu hubungan yang ada sangat mutualisme. Walaupun pengelolaan kawasan konservasi di Jawa Barat di pegang oleh Balai Besar Konservasi Sumber Daya Alam (BKSDA) Jawa Barat. Begitu pula kawasan konservasi Taman Buru Masigit Kareumbi, salah satu kawasan konservasi Taman Buru Nasional satu-satunya yang ada di Pulau Jawa. Untuk pengelolaanya di 
pegang penuh oleh Balai BKSDA Jawa Barat sebagai perpanjang tanganan pemerintah di bawah langsung dari Kementrian Kehutanan dan Direktorat Jenderal Perlindungan Hutan dan Konservasi Alam (PHKA). Balai BKSDA memiliki visi dan misi dalam mengelola kawasan konservasi di Jawa Barat.

Sedangkan Wanadri merupakan organisasi Perhimpunan Penempuh Rimba dan Pendaki Gunung yang mempunyai keter-tarikan dalam melestarikan lingkungan sekitar. Sesuai dengan janji dan hakekat yang di pegang teguh oleh setiap anggota Wanadri.

3. Mencari tahu siapa saja yang terlibat. (Finding out who is involved)

Berdasarkan permasalahan tersebut, maka pihak yang terlibat adalah pihak yang memiliki keentingan dan juga memiliki kepedulian dalam pengelolaan kawasan tersebut.

Berdasarkan penjelasan sebelumnya maka dalam kolaborasi pengelolaan kawasan konservasi Taman Buru Masigit Kareumbi, terdapat pihak-pihak yang terlibat dalam pengelolaannya yaitu Balai BKSDA Jawa Barat dan Wanadri. Balai BKSDA di bantu oleh beberapa bagian yang ikut serta dalam mengelola kawasan konservasi Taman Buru Masigit Kareumbi, yaitu Kepala Bidang Teknis KSDA Jawa Barat, Kepala Sub Bagian Perencanaan dan Kerjasama, Kepala Seksi Wilayah II Soreang, dan Kepala Resort Masigit Kareumbi Barat. Sedangkan Wanadri di dalam pengelolaan kawasan koservasi menunjuk Koperasi Wanadri untuk membuat Usaha Unit Otonom (UUO) dalam mengelola kawasan konservasi TBMK, lalu terbentuklah Tim Manajemen Pengelola Kawasan Konservasi Taman Buru Masigit Kareumbi.

Balai BKSDA Jawa Barat dan Wanadri keduanya memiliki kesamaan tujuan awal atau visi dan misi yang di punya oleh setiap organisasi. Keduanya sama-sama fokus dalam menjaga, melindungi, dan melestarikan lingkungan sekitarnya. Dalam hal pemahaman tujuan utama tentunya beracuan pada orang atau instansi yang memiliki ide awal untuk mengelola kawasan konservasi Taman Buru Masigit
Kareumbi. Awal mula berasal ketika perjalanan oleh salah satu sesepuh Wanadri yang sering melakukan perjalanan ke kawasan konservasi Taman Buru Masigit Kareumbi, Remi Tjahari (W-090-LANG) melihat potensi kawasan yang sangat besar. Maka timbul suatu ketertarikan dalam megelola kawasan konservasi Taman Buru Masigit Kareumbi. Akhirnya Wanadri menyampaikan minatnya untuk mengelola kawasan konservasi Taman Buru Masigit Kareumbi dan hal itu pun di sambut baik oleh Balai BKSDA Jawa Barat, lalu terbentuklah suatu kesepakatan bersama dalam bentuk MoU (Memorandum of Understanding) tentang "Optimalisasi Pengelolaan Kawasan Konservasi Taman Buru Masigit Kareumbi" sebagai acuan dan pegangan dalam pengelolaan kawasan konservasi Taman Buru Masigit Kareumbi.

Menurut beberapa informan semua pihak terlibat mengetahui tujuan dalam melakukan pengelolaan kawasan. Hal itu pun senada yang di ungkapkan oleh informan 4, Balai BKSDA Jawa Barat dan Wanadri memiliki kesamaan tujuan yang tertuang dalam MoU (Memorandum of Understanding) serta setiap pihak mengetahui tujuannya tersebut. Dari hasil wawancara yang peneliti lakukan, dari beberapa informan mengatakan hal yang senada bahwa baik dari Balai BKSDA Jawa Barat dan Wanadri mengetahui tujuan dalam mengelola kawasan konservasi Taman Buru Masigit Kareumbi sesuai dengan Mou (Memorandum of Understanding) yang telah di sepakati.

4. Mencari tahu bagaimana pengimplementasiannya. (Finding out how to implement)

Setiap pihak yang terlibat baik dari Balai BKSDA Jawa Barat dan Wanadri sudah mengetahui tujuan dalam mengelola kawasan konservasi Taman Buru Masigit Kareumbi. Sesuai dengan isi dari Mou (Memorandum of Understanding) di salah satu poin mengenai maksud, tujuan, dan sasaran yaitu :

(1) Maksud kerjasama adalah agar Taman Buru Masigit Kareumbi berfungsi sebagai kawasan konservasi, pendidikan, wisata alam, dan wisata buru yang menjadi model pengelolaan Taman Buru khususnya, dan 
kawasan konservasi pada umumnya.

(2) Tujuan kerjasama adalah agar Taman Buru Masigit Kareumbi didayagunakan secara lestari dan berkelanjutan serta memberi manfaat lingkungan, ekonomi, social, dan budaya kepada masyarakat di dalam dan sekitar kawasan.

(3) Sasaran kerjasama adalah :

a. Terlaksananya pengelolaan Taman Buru Masigit Kareumbi yang optimal dan lestari, sesuai dengan peruntukannya;

b. Terwujudnya peningkatan peran serta masyarakat dalam upaya konservasi sumber daya alam hayati dan ekosistemnya;

c. Terjaganya keamanan dan terpeliharanya keutuhan kawasan Taman Buru Masigit Kareumbi;

d. Terselenggaranya fungsi Taman Buru Masigit Kareumbi secara optimal sebagai wilayah perlindungan sistem penyangga kehidupan.

Dengan adanya penjelasan paragraf sebelumnya, di harapkan setiap pihak yang terlibat mampu menjalankan isi dari maksud, tujuan, dan sasaran tersebut. Meskipun setiap organisasi mempunyai tujuan yang berbeda tetapi dari perbedaan tersebut dapat disatukan dalam kesepakatan bersama dengan bentuk MoU (Memorandum of Understanding) dalam pengelolaan kawasan konservasi Taman Buru Masigit Kareumbi. Sehingga kedua belah pihak dapat menentukan langkah bagaimana cara untuk mewujudkan dan mencapai tujuan tersebut.

Di perlukan juga keterlibatan masyarakat sebagai mitra atau partner bagi Balai BKSDA Jawa Barat dan Wanadri untuk ikut berperan serta dalam membantu mewujudkan dan mencapai tujuan tersebut. Hal itu dilakukan untuk meminimalisir pengrusakan di kawasan konservasi Taman Buru Masigit Kareumbi seperti adanya penebangan pohon secara liar, perburuan binatang, dll. Hal itu sesuai dengan salah poin di dalam sasaran kerjasama, (b) Terwujudnya peningkatan peran serta masyarakat dalam upaya konservasi sumber daya alam hayati dan ekosistemnya, dan (c) Terjaganya keamanan dan terpeliharanya keutuhan kawasan
Taman Buru Masigit Kareumbi. Kedua poin tersebut menjelaskan secara jelas bahwa pengelolaan kawasan konservasi tidak dapat berjalan dengan optimal apabila tidak di sertakan bantuan masyarakat untuk menjaga, melindungi, dan melestarikan kawasan konservasi Taman Buru Masigit Kareumbi.

5. Menyelenggarakan kolaborasi. (Launching implementation)

Agar penyelenggaraan program ini dapat berjalan dengan baik setidaknya terdapat hal yang harus dilakukan, antaranya : para stakeholders bersama-sama melakukan program tersebut dengan metode yang sudah ditentukan bersama dan memikirkan kembali dan mendefinisikan tujuan serta menentukan indikatorindikator kerja untuk seluruh proses kolaborasi.

Dalam kolaborasi pengelolaan Kawasan Masigit, terdapat perencanaan konsep pengelolaan kawasan konservasi Taman Buru Masigit Kareumbi di tuangkan dalam bentuk RKT (Rencana Kerja Tahunan) sebagai gambaran atau penjelasan mengenai berbagai kegiatan dan program yang akan dilaksanakan. RKT menjadi bahan acuan atau pegangan bagi Balai BKSDA Jawa Barat dan Wanadri untuk melaksanakan kegiatan pengelolaan.

Sebelum melakukan kegiatan dalam pengelolaan kawasan konservasi Taman Buru Masigit Kareumbi, draft RKT terlebih dahulu di buat oleh Manajemen Pengelola TBMK yang di bawah otoritas dari Koperasi Wanadri lalu ketika awal tahun diserahkan kepada Balai BKSDA Jawa Barat untuk dinilai bagaimana isi dari kelengkapan RKT tersebut. Apabila isi dari RKT telah sesuai dengan apa yang di inginkan maka disahkan oleh Balai BKSDA Jawa Barat. dan dijadikan bahan acuan bagi para pengelola khususnya Manajemen Pengelola TBMK untuk melakukan suatu kegiatan dan program di dalam kawasan.

Menurut hasil wawancara dari beberapa informan, dalam perencanaan konsep pengelolaan kawasan konservasi Taman Buru Masigit Kareumbi semua pihak terlibat. Akan tetapi pada awal tahun pertama dalam melakukan pengelolaan kawasan konservasi Taman Buru Masigit 
Kareumbi, RKT (Rencana Kerja Tahunan) belum pernah sama sekali dibahas ataupun dievaluasi oleh berbagai pihak yang terlibat. Hal ini menjadikan suatu pertanyaan besar bagi pihak-pihak yang terlibat bagaimana proses kolaborasi yang dijalankan dalam pengelolaan kawasan konservasi Taman Buru Masigit
Kareumbi. Adanya ketidaksesuain dalam isi MoU (Memorandum of Understanding) dengan fakta yang terjadi dilapangan, terdapat di dalam isi hak dan kewajiban bahwa "Bersama-sama melakukan kegiatan monitoring dan evaluasi optimalisasi pengelolaan kawasan konservasi Taman Buru Masigit Kareumbi.”

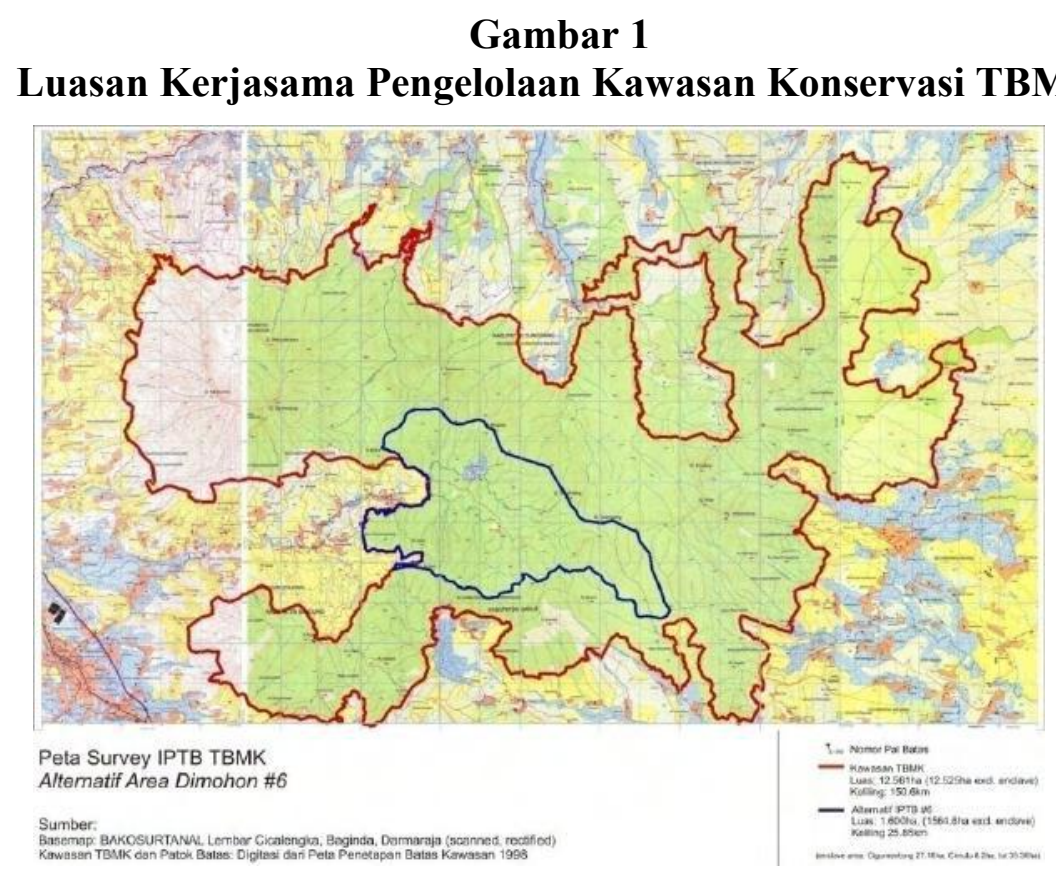

(Sumber : Manajemen Pengelola TBMK, 2013)

Adanya pembahasan dalam RKT (Rencana Kerja Tahunan) pada tahun 2013, di harapkan menjadi suatu awal yang baik dalam keberlangsungan kolaborasi dalam pengelolaan kawasan konservasi Taman Buru Masigit Kareumbi. Balai BKSDA Jawa Barat dan Wanadri dapat mengetahui bagaimana peranannya dalam menjalankan RKT sebagai bahan acuan dalam melakukan pengelolaan kawasan.

\section{Mengevaluasi proses tersebut. (Evaluating the process)}

Evaluasi merupakan peran instrumental dari hasil proses kolaborasi bersama di dalam kolaborasi, dimana menilai dampak dan perubahan bagi organisasi tersebut, bagi anggota organisasi, atau bagi masyarakat yang mereka layani.
Dalam kolaborasi pengelolaan kawasan Masigit, monitoring dan evaluasi dilakukan oleh pihak BKSDA. Kemudian untuk tugas dan peran masing-masing pihak baik Balai BKSDA Jawa Barat dan Wanadri, dari hasil observasi dan wawancara yang peneliti lakukan bahwa Balai BKSDA Jawa Barat belum secara optimal melaksanakan tugas hak dan kewajibannya. Hal itu terlihat dengan jarangnya intensitas monitoring langsung oleh Resort Masigit Kareumbi Barat ke dalam kawasan dikarenakan kekurangan sumber daya manusia. Sesuai dengan isi pernjanjian kerjasama atau MoU (Memorandum of Understanding) di dalam pasal 4 mengenai hak dan kewajiban ayat 1 poin b menjelaskan bahwa pihak pertama yaitu Balai BKSDA Jawa Barat melakukan kegiatan monitoring dan evaluasi optimalisasi pengelolaan kawasan Taman Buru Masigit Kareumbi. 
Berdasarkan pembahasan tersebut Kolaborasi dalam pengelolaan kawasan konservasi Taman Buru Gunung Masigit Kareumbi terjadi karena adanya hubungan saling ketergantugan dalam mengelola kawasan hutan konservasi. Pengelolaan kawasan konservasi khususnya Taman Buru Gunung Masigit Kareumbi yang cukup sulit dikelola oleh Balai Besar Konservasi Sumber Daya Alam dikarenakan keterbatasan sumber daya yang dimiliki maka dibutuhkan peran dari pihak lain dalam membantu pengelolaan yaitu Wanadri dan masyarakat sekitar kawasan Taman Buru Gunung Masigit Kareumbi. Dengan demikian dengan menggunakan konsep Vigoda dan Gilboa (2002) juga menjelaskan bahwa kolaborasi terjadi ketika adanya orang dari berbagai pihak terkait untuk bekerjasama dalam merencanakan, membuat, memecahkan masalah, dan membuat keputusan. Hal ini pun sesuai dengan kolaborasi yang dilakukan oleh BBKSDA dan Wanadri dalam melakukan pengelolaan kawasan konservasi Taman Buru Gunung Masigit Kareumbi. Kedua belah pihak bekerjasama dan menempatkan orang-orang dalam melakukan pengelolaan.

Dalam pelaksanaan kolaborasi kawasan konservasi Taman Buru Gunung Masigit Kareumbi, Balai Besar Konservasi Sumber Daya Alam merupakan lembaga dari lingkungan pemerintah yang mengelola kawasan konservasi dengan di bantu beberapa unit lembaga seperti Bidang KSDA Wilayah II Soreang, Seksi Wilayah III KSDA Soreang dan Resort Masigit Kareumbi Barat. Dan Perhimpunan Penempuh Rimba dan Pendaki Gunung Wanadri sebagai lembaga non pemerintah yang melakukan kerjasama dengan BBKSDA terkait pengelolaan kawasan konservasi Taman Buru Gunung Masigit Kareumbi.

Secara teoritis diharapkan pelaksanaan kolaborasi antar instansi yang merupakan aktifitas pengintegrasian dan penyelarasan seluruh kegiatan dari berbagai unit kerja dan personil yang berlainan fungsi dan instansi, dengan berpedoman kepada proses dalam kolaborasi, dapat menghasilkan kolaborasi pengelolaan kawasan konservasi Taman Buru
Masigit Kareumbi yang efektif, selaras, dan sinergis sebagaimana yang diharapkan dalam Peraturan Menteri Kehutanan Nomor : P.19/Menhut-II/2004 tentang Kolaborasi Pengelolaan Kawasan Suaka Alam dan Kawasan Pelestarian Alam.

Namun masih belum kuatnya hubungan diantara keduanya yang mengakibatkan ketidaksepahaman dalam menjalankan pengelolaan kawasan konservasi Taman Buru Masigit Kareumbi. Tugas dan peran masing-masing pihak dapat lebih dimengerti apabila ada SOP (Standar Operasional Prosedur) yang menjadi dasar dalam pembagian tugas dan peran. Ketika adanya kesadaran dan keseriusan dalam menjalankan pengelolaan dengan ditambah lagi adanya SOP maka pelaksanaan pengelolaan kawasan konservasi Taman Buru Masigit Kareumbi akan berjalan dengan baik dan hubungan antara Balai BKSDA Jawa Barat dengan Wanadri akan kuat dan akan terbentuk keharmonisan dalam menjalankan pengelolaan kawasan konservasi Taman Buru Masigit Kareumbi serta hal itu dapat memudahkan bagi setiap pihak terlibat dalam mencapai tujuan bersama. Keterlibatan masyarakat lokal diperlukan dalam mencapai tujuan pengelolaan kawasan, hal itu diperlukan untuk membantu Balai BKSDA dan Wanadri dalam menjalankan setiap kegiatan atau program yang akan dilaksanakan sehingga akan terbentuk kolaborasi yang benar-benar selaras dan sinergis.

\section{Simpulan}

Kolaborasi yang dilakukan dalam pengelolaan Kawasan Masigit Kareumbi bahwa pihak yang terlibat adalah dari pihak organisasi lokal yaitu Wanadri dan juga BKSDA Provinsi Jawa Barat. Sedangkan dari pihak pemerintah kabupaten (Kab. Garut, Kab. Bandung, dan Kab. Sumedang). Tidak terlibat dalam kolaborasi karena mereka beranggapan tidak memiliki kewenangan dalam pengelolaan wilayah tersebut.

Maka dari itu kolaborasi yang dilakukan sudah dilakukan dengan baik dan dapat berjalan bahkan sampai mengeluarkan dalam bentuk 
MoU yang dapat memperkuat kolaborasi yang dilakukan dalam pengelolaan kawasan tersebut. Hanya dalam konsep dari Vigoda, bahwa kegiatan kolaborasi yang dilakukan dalam pengelolaan Kawasan Kareumbi tersebut sudah mengikuti tahapan-tahapan dalam kolaborasi bahkan sampai proses monitoring dan evaluasi.

Namun hubungan ini melemah karena ketidaksepahaman dalam menjalankan pengelolaan kawasan konservasi Taman Buru Masigit Kareumbi. Tugas dan peran masing-masing pihak tidak dapat dimengerti karena belum ada SOP (Standar Operasional Prosedur) yang menjadi dasar dalam pembagian tugas dan peran tiap stakeholder.

\section{Rekomendasi}

Dalam kekuatan untuk kolaborasi sudah ada, hanya berdasarkan hasil simpulan bahwa dalam kolaborasi masih ada ketidaksepahaman karena tidak adanya aturan khusus yang melibatkan seluruh stakeholder termasuk pemerintah dari level Provinsi, hingga level kabupaten yaitu Kabupaten Garut, Kabupaten Bandung, dan Kabupaten Sumedang.

Aturan yang sudah terbentuk harus diturunkan dalam bentuk rencana aksi Bersama atau SOP, maka rekomendasi dalam penelitian ini adalah SOP agar setiap stakeholder yang terlibat dalam pengelolaan kawasan tersebut. Kemudian penyusunan SOP ini harus melibatkan setiap stakehoder agar setiap stakholder dapat memahami apa yang harus dia lakukan dalam pengelolaan kawasan.

\section{DAFTAR PUSTAKA}

\section{A. Buku}

Agranoff, Robert ; Mc. Guire Michael. 2003. Collaborative Public management. Washington, D.C : Goergetown University Press.

Furchan, A. 2004. Pengantar Penelitian dalam Pendidikan. Yogyakarta : Pustaka Pelajar.
Creswell, John W. 2002. Desain Penelitian, Pendekatan Kualitatif dan Kuantitatif: Jakarta: KIK Press.

Linden, Russell M. 2002. Working Across Boundaries. Jossey - Bass A Wiley Imprint.

Miles, Mathew B. Dan A. Michael Huberman. 1992. Analisis Data Kualitatif Buku Sumber tentang Metode-Metode Baru. Jakarta. Universitas Indonesia (UI - Press).

O'Flynn, Janine. Wanna, John. 2008. Collaboraive Governance : A New Era of Public Policy in Australia. Australia : Australia National University Press.

Satori, Djam'an : Komariah, Aan. 2010. Metodologi Penelitian Kualitatif. Bandung : Alfabeta.

Sugiyono. 2012. Metode Penelitian Kuantitatif, Kualitatif, Dan Kombinasi (Mixed Methods). Bandung : Alfabeta.

.2009. Metode Penelitian Kuantitatif Kualitatif dan R\&D. CV. Alfabeta

Straus, David. 2002. How to Make Collaboration Work. San Fransisco : Berret - Koehler Publishers, Inc.

Tadjudin, Djuhendi. 2000. Manajemen Kolaborasi. Bogor : Pustaka Latin.

Vigoda, Evan. 2002. An Interdisciplinary Critical Analysis. New York: Marcel Dekker, Inc.

\section{B. Jurnal}

Huxham, Chris and Vangen, Siv (1996). Working together, key themes in the management of relationships between public and nonprofit organizations. International Journal of Public Sector Management, 9(7) pp. 517.

Thompson, Ann Marie. Collaboration Process : Inside The Black Box. 